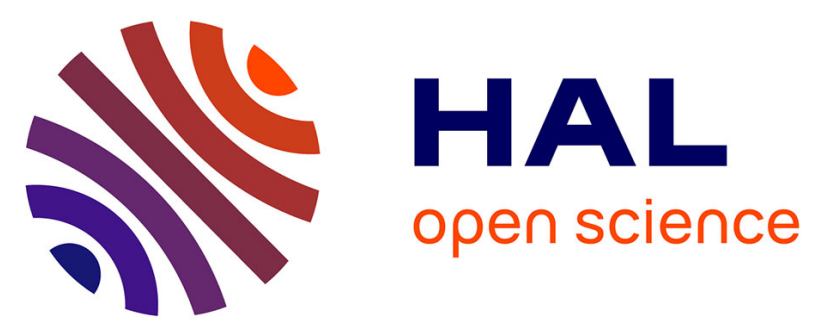

\title{
Efficacy of Azacitidine in Autoimmune and Inflammatory Disorders associated with Myelodysplastic Syndromes and Chronic Myelomonocytic Leukemia
}

Jean-Baptiste Fraison, Arsène Mekinian, Eric Grignano, Jean-Emmanuel Kahn, Jean-Benoit Arlet, Olivier Decaux, Guillaume Denis, Anne-Laure Buchdahl, Mohamed Omouri, Gwenola Maigne, et al.

\section{To cite this version:}

Jean-Baptiste Fraison, Arsène Mekinian, Eric Grignano, Jean-Emmanuel Kahn, Jean-Benoit Arlet, et al.. Efficacy of Azacitidine in Autoimmune and Inflammatory Disorders associated with Myelodysplastic Syndromes and Chronic Myelomonocytic Leukemia. Leukemia Research, 2016, 43, pp.13-17. 10.1016/j.leukres.2016.02.005 . hal-01278608

\section{HAL Id: hal-01278608 \\ https://hal-univ-rennes1.archives-ouvertes.fr/hal-01278608}

Submitted on 7 Jun 2016

HAL is a multi-disciplinary open access archive for the deposit and dissemination of scientific research documents, whether they are published or not. The documents may come from teaching and research institutions in France or abroad, or from public or private research centers.
L'archive ouverte pluridisciplinaire HAL, est destinée au dépôt et à la diffusion de documents scientifiques de niveau recherche, publiés ou non, émanant des établissements d'enseignement et de recherche français ou étrangers, des laboratoires publics ou privés. 


\section{Accepted Manuscript}

Title: Efficacy of Azacitidine in Autoimmune and Inflammatory Disorders associated with Myelodysplastic Syndromes and Chronic Myelomonocytic Leukemia

Author: Fraison Jean-Baptiste Mekinian Arsène Grignano Eric Kahn Jean-Emmanuel Arlet Jean-Benoit Decaux Olivier

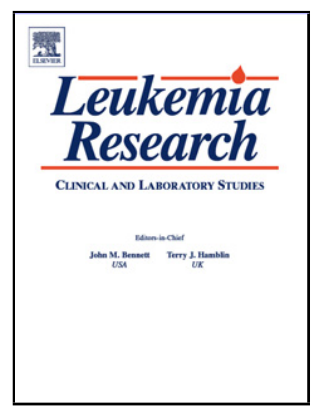
Denis Guillaume Buchdahl Anne-Laure Omouri Mohamed Maigne Gwenola Aouba Achille Leon Nathalie Berthier Sabine Liozon Eric Park Sophie Gardin Claude Lortholary Olivier Rossignol Julien Fenaux Pierre Fain Olivier Braun Thorsten

PII:

DOI:

Reference: S0145-2126(16)30020-0 http://dx.doi.org/doi:10.1016/j.leukres.2016.02.005

To appear in: $\quad$ Leukemia Research

Received date: $\quad$ 14-12-2015

Revised date: $\quad$ 4-2-2016

Accepted date: $\quad 14-2-2016$

Please cite this article as: Jean-Baptiste Fraison, Arsgraveene Mekinian, Eric Grignano, Jean-Emmanuel Kahn, Jean-Benoit Arlet, Olivier Decaux, Guillaume Denis, Anne-Laure Buchdahl, Mohamed Omouri, Gwenola Maigne, Achille Aouba, Nathalie Leon, Sabine Berthier, Eric Liozon, Sophie Park, Claude Gardin, Olivier Lortholary, Julien Rossignol, Pierre Fenaux, Olivier Fain, Thorsten Braun.Efficacy of Azacitidine in Autoimmune and Inflammatory Disorders associated with Myelodysplastic Syndromes and Chronic Myelomonocytic Leukemia.Leukemia Research http://dx.doi.org/10.1016/j.leukres.2016.02.005

This is a PDF file of an unedited manuscript that has been accepted for publication. As a service to our customers we are providing this early version of the manuscript. The manuscript will undergo copyediting, typesetting, and review of the resulting proof before it is published in its final form. Please note that during the production process errors may be discovered which could affect the content, and all legal disclaimers that apply to the journal pertain. 


\section{Efficacy of Azacitidine in Autoimmune and Inflammatory Disorders associated with Myelodysplastic Syndromes and Chronic Myelomonocytic Leukemia}

Running title: Azacitidine in autoimmune disorders associated with MDS/CMML

Fraison Jean-Baptiste*1, Mekinian Arsène ${ }^{\star 2}$, Grignano Eric ${ }^{3}$, Kahn Jean-Emmanuel ${ }^{4}$, Arlet Jean-Benoit ${ }^{5}$, Decaux Olivier ${ }^{6}$, Denis Guillaume ${ }^{7}$, Buchdahl Anne-Laure ${ }^{8}$, Omouri Mohamed ${ }^{9}$, Maigne Gwenola ${ }^{10}$, Aouba Achille ${ }^{10}$, Leon Nathalie ${ }^{11}$, Berthier Sabine ${ }^{12}$, Liozon Eric ${ }^{13}$, Park Sophie ${ }^{14}$, Gardin Claude ${ }^{15}$, Lortholary Olivier ${ }^{16}$, Rossignol Julien ${ }^{3}$, Fenaux Pierre ${ }^{17}$, Fain Olivier $^{* 2}$ and Braun Thorsten ${ }^{* 15}$.

1 Service de Médecine Interne, Hôpital Jean Verdier, Assistance Publique des Hôpitaux de Paris, université Paris XIII, 2 Service de Médecine Interne, DHU i2B, inflammation-immunopathologie-biothérapie (DHU i2B), Hôpital Saint Antoine, Assistance Publique des Hôpitaux de Paris, université Paris VI Sorbonne, $75012 \quad$ Paris, $\quad$ France. 3 Service d'hématologie, Institut de Cancérologie Gustave Roussy, 94800 Villejuif, France. 4 Service de Médecine Interne, Hôpital Foch, Suresnes, France. 5 Service de Médecine Interne, Hôpital Européen Georges Pompidoux, université Paris V, Paris, France.

6 Service de Médecine Interne, Centre Hospitalier Universitaire de Rennes, France. 7 Service de Médecine Interne, Centre Hospitalier de Rochefort, France. 8 Service de Médecine Interne, Centre Hospitalier de Douai, France. 9 Service de Rhumatologie, Centre Hospitalier de Romilly, France. 10 Service de Médecine Interne, Centre Hospitalier Universitaire de Caen, France. 11 Service de Rhumatologie, Centre Hospitalier Universitaire de Caen, France 12 Service de Médecine Interne, Centre Hospitalier Universitaire de Dijon, France. 13 Service de Médecine Interne, Centre Hospitalier Universitaire de Limoges, France. 14 Service d'Hématologie, Centre Hospitalier Universitaire de Grenoble, France. 15 Service d'Hématologie, Hôpital Avicenne, université Paris XIII,Bobigny, France. 16 Service de Maladies Infectieuses, Hôpital Necker, université Paris V, Paris, France. 17 Service d'Hématologie, Hôpital Saint Louis, université Paris VII, Paris, France.

Corresponding author:

Fraison JB (MD) Service de Médecine Interne, av du 14 juillet, Hôpital Jean Verdier, 93140 Bondy, APHP, université Paris XIII, France. Phone number: $\quad(+33) 148026861, \quad$ Fax number: $\quad(+33) 148026361$ E-mail: jeanbaptiste.fraison@aphp.fr

* Contributed equally to this work 


\section{Highlights}

1) AID associated to MDS/CMML is difficult to manage

2) Azacitidine can improve the control of AID associated with MDS/CMML.

3) Azacitidine allows to reduce steroid dose in most MDS patients with concurrent AID

4) Azacitidine can be beneficial on AID, even when inactive on the underlying MDS/CMML.

\section{Summary}

This retrospective study describes efficacy of Azacitidine on autoimmune disorders (AID) associated with MDS/CMML in 22 patients. Response of AID to Azacitidine was observed in 19 patients (86\%). Reduction or discontinuation of steroids and/or immunosuppressive therapy (IST) was possible in 16 cases (73\%). Hematologic response was seen in $55 \%$ of the patients. MDS/CMML and AID evolution was concordant in 13 cases $(59 \%)$ : both favorable $(n=11)$, both unfavorable $(n=2)$, but AID improved while MDS/CMML worsened $(n=8)$ and vice versa $(n=1)$. Azacitidine frequently seems effective in controlling steroid-dependent AID associated with MDS/CMML, but prospective studies are necessary to confirm those findings.

Key words: Azacitidine, myelodysplastic syndromes, auto immune disorders. 


\section{Introduction}

Autoimmune disorders are observed in 10 to $30 \%$ of MDS and CMML, typically diagnosed concomitantly or shortly before or after MDS/CMML [1].

Most common AID associated with MDS/CMML include relapsing polychondritis, vasculitis, non-erosive and seronegative arthritis [2,3] and Sweet's syndrome [4]. While AID associated with MDS/CMML usually respond to corticosteroids [2], many patients remain steroid dependent or resistant, requiring additional IST, a situation which increases the risk of severe cytopenias and infections in the context of MDS/CMML [1].

Azacitidine significantly improves survival in higher risk MDS [5] and in myelodysplastic type CMML [6,7] and is also approved outside Europe for the treatment of lower risk MDS. Seven patients with MDS/CMML and AID treated with Azacitidine have been reported to our knowledge [8-11].

\section{Methods}

We retrospectively analyzed the efficacy of Azacitidine in MDS/CMML patients with concomitant AID seen between 2007 and May 2014 in registries of the Société Nationale Française de Médecine Interne (SNFMI) and of the Groupe Francophone des Myélodysplasies. The SNFMI registry included 123 MDS/CMML patients with AID in 26 centres) [13], while the GFM registry included 4202 MDS/CMML in 30 centres of whom 80 also had documented AID. The GFM registry has been so far the basis for many publications of the GFM or that included the GFM [14-16].

Inclusion criteria for the present study were (i) complete or atypical AID according to usual international criteria [17], (ii) MDS or non-proliferative CMML (ie with WBC<13G/L), classified according to WHO 2008 criteria [18] but also including 
patients with up to $30 \%$ marrow blasts, (iii) treatment with at least one cycle of Azacitidine.

Patients were excluded if AID were caused by infectious disease, AID were in remission without steroids or IST at Azacitidine onset, or if IST was administered more than 12 months before diagnosis of MDS, suggesting MDS secondary to IST.

Complete/ partial remission (CR/PR) of AID after Azacitidine were defined by complete/partial disappearance of clinical or biological signs with stable dose or decrease/discontinuation of steroids or IST, as previously defined [2]. Hematological response to Azacitidine was classified according to IWG 2006 criteria [18].

For statistical analysis, Wilcoxon test was used for analysis of paired quantitative variables and Fisher's exact test for paired qualitative variables using $R$ 3.2.1 (2015) with package Rcmdr 2.1-7 (2007).

\section{Results}

Among patients with both MDS/CMML and AID included in the 2 registries, twenty eight patients had received Azacitidine (flow chart in figure 1). Six were excluded, because AID were in remission without IST at Azacitidine onset $(n=2)$, of inadequate follow-up $(n=3)$ and as vasculitis was post-infectious $(n=1)$. Median age of the 22 remaining patients was 70 years (range 41-84), including 6 females and 16 males (73\%). (Table 1)

Diagnosis of MDS/CMML preceded AID diagnosis $(n=8$; by a median of 17 months), was concomitant with $(n=7)$ or followed AID diagnosis ( $n=7$; by a median of 20 months). 


\section{AID and MDS characteristics}

At MDS/CMML diagnosis, 14 patients had low or int-1 IPSS and 8 had int-2 or high IPSS. The 2 cases of CMML with WBC below 13G/L were classifiable by IPSS. AID diagnosis included: Behçet's disease $(n=4)$, polymyalgia rheumatica $(n=3)$, polymyalgia rheumatica with giant cell arteritis $(n=1)$, giant cell arteritis $(n=1)$, relapsing polychondritis $(n=3)$, polychondritis with Sweet's syndrome $(n=1)$, Sweet's syndrome $(n=1)$, systemic lupus erythematous $(n=2)$, seronegative polyarthritis $(n=2)$, Sjögren's syndrome with anti-phospholipid syndrome $(n=1)$, adult onset Still's disease $(n=1)$, large vessel vasculitis $(n=1)$ and unclassified small vessel vasculitis $(n=1)$. Twelve $(55 \%)$ AID were considered atypical and $10(45 \%)$ fulfilled complete diagnostic criteria.

\section{AID features at Azacitidine onset}

At Azacitidine onset, AID was still active $(n=15)$, in PR $(n=5)$ and in CR $(n=2)$. Nineteen patients still reported clinical symptoms related to AID including asthenia $(n=17)$, weight loss $(n=8)$, fever $>38.5^{\circ} \mathrm{C}(n=8)$, rheumatologic signs $(n=15)$, skin involvement $(n=10)$, oral aphtosis $(n=4)($ Table 1$)$. Twenty $(91 \%)$ patients were receiving steroids (median: $23 \mathrm{mg} /$ day) for a median duration of 11 months (range 1101) with no efficacy $(n=13)$, partial efficacy $(n=5)$ and full efficacy on AID $(n=2)$. In

patients where steroids were ineffective, they were however generally continued to avoid AID flare. The median duration of steroid use, in the 18 good responders on AID, was 16 months (range 1-101) versus 9 (range 8-9) in the non-responders. Thirteen patients were non-responders to IST and 11 received concomitant treatment with IST and steroids: without efficacy in 7 patients, partial efficacy in 2 and full efficacy in 2 (Table 1). Onset of IST preceded that of Azacitidine by a median of 7 
months (range 1-50); the 3 patients who did not have a good response on AID did not receive IST.

Median interval between MDS/CMML diagnosis and Azacitidine onset was 9 months (range 1-93). Azacitidine was the first-line treatment of MDS/CMML in 16 patients $(73 \%)$ and was in 6 patients preceded by lenalidomide $(n=2)$, hydroxyurea $(n=2)$, idarubicin $(n=1)$ and low dose cytarabine $(n=1)$, treatments to which AID had not responded in any patient.

\section{MDS features at Azacitidine onset}

At Azacitidine onset, 11 patients had int-2 or high IPSS, and Azacitidine was used according to the drug label in EU; in the 11 low or int-1 IPSS, reasons to start Azacitidine were RBC transfusion dependence or severe thrombocytopenia in 8 patients ( 6 of whom also had AID flare) and AID flare alone in 3 patients (Table1).

\section{AID response}

Patients received a median of 6 cycles of Azacitidine (range 3-14). CR of AID was observed in 16 patients (73\%), PR in 3 cases (14\%) and no effect or worsening of AID in 3 cases (14\%). All responses were observed within 3 cycles, but 8 PR after 3 cycles became CR after 6 months. In the 3 patients treated with Azacitidine for AID flare alone, one achieved $\mathrm{CR}$, one PR and the last patient did not respond. Steroids were tapered from $40 \mathrm{mg} /$ day to $16 \mathrm{mg} /$ day in one patient and IST was discontinued in another patient.

Median prednisone dose was reduced from $23 \mathrm{mg} /$ day to $9 \mathrm{mg} / \mathrm{day}(\mathrm{p}=0.001)$, including prednisone discontinuation in 3 patients (14\%) and dose reduction in 14 patients (64\%) (Table1). IST discontinuation was possible in 7 patients (32\%). In the 9 steroid-dependent or resistant patients, median prednisone dose was decreased from $50 \mathrm{mg} /$ day to $5 \mathrm{mg} /$ day $(p=0.01)$ and prednisone discontinuation was possible in 
3 patients. IST discontinuation was possible in the 3 patients who received them. After Azacitidine treatment, median CRP levels decreased from 40 (range 0-300) to $15 \mathrm{mg} / \mathrm{L}$ (range 0-146) $(\mathrm{p}=0.28)$.

\section{MDS response}

Response of MDS/CMML to Azacitidine was seen in 12 patients (55\%), including CR in 9 patients (41\%), PR in 1, stable disease with erythroid response in 1, marrow CR in 1, stable disease without response of cytopenias in 8 and progression in 2 .

MDS/CMML and AID evolution were concordant in 13 cases (59\%): both improved $(n=11)$ or worsened $(n=2)$. In the other patients, AID improved while MDS worsened $(n=8)$ and vice versa $(n=1)$.

\section{Side effects/ Evolution}

Adverse events occurring during Azacitidine treatment included: 9 grade 2-3 infections ( 6 of them occurred in Int-2 or high IPSS patients), 1 fatal CNS bleeding, 1 deep vein thrombosis, 1 Interstitial lung disease.

Only 3 relapses of AID were seen after 3, 19 and 19 months respectively, and 5 patients had response duration $\geq 12$ months, but median follow-up from response to Azacitidine was only 8 months (Table1).

Seven patients (32\%) progressed to $A M L$ and 10 patients (45\%; including $80 \%$ of IPSS int-2 and high risk patients) had died, from CNS bleeding $(n=3)$, severe infection $(n=5)$, progression in AML $(n=1)$ and myocardial infarction $(n=1)$. Among the 10 patients who died, 6 had progressed to AML. Severe infections were more frequently linked to $A M L$ progression than to Azacitidine. Median survival from Azacitidine onset was 16 months in IPSS high or int-2 MDS, and was not reached in IPSS low and int-1 MDS. 


\section{Discussion}

Azacitidine improved clinical signs of AID in $86 \%$ of the cases $(73 \% \mathrm{CR}, 14 \% \mathrm{PR})$ in patients with MDS/CMML.Azacitidine also allowed to reduce the steroid dose in $64 \%$ of the patients and discontinuation of other IST in $32 \%$ of them.

In patient $n^{\circ} 5$, Azacitidine allowed to discontinue both MMF and hydroxychloroquine without having an AID flare. In patient $n^{\circ} 10$, prolonged clinical and biological complete response was maintained under Azacitidine without requirement of new IST or steroids.

In the only 7 cases of AID with MDS/CMML treated with Azacitidine published so far to our knowledge, 6 were refractory to steroids and/or IST and 4 had higher risk IPSS. MDS and AID evolution were concordant in six cases (Table 2) [8-11].

In our series, all responses of AID to Azacitidine were seen by the third cycle, although about one third of responses improved and became complete between 3 and 6 cycles. Furthermore, although less than $50 \%$ of the patients received more than 6 cycles of Azacitidine, only 3 relapses were observed (but with a median follow-up from response of AID to Azacitidine of only 8 months).

Most of the MDS/CMML included in the present study required some treatment because of high or int-2 IPSS in 11 cases, RBC transfusion dependence or severe thrombocytopenia in 8 cases. In the last 3 patients, however AID flare refractory to IST and/or high dose steroids was the only reason to start Azacitidine.

The concordant evolution of AID and MDS/CMML we observed in $59 \%$ of the cases further supports a pathophysiological link between MDS/CMML and AID. However, it often remains unclear, in MDS/CMML associated with AID, which of the 2 diseases is the cause and which is the consequence. While immunological defects may potentially trigger MDS/CMML, they may also be in some cases the consequences of 
MDS/CMML, when some cells of the immune system are part of the MDS/CMML clone $[1,11]$. In addition to its direct pro-apoptotic activity on MDS cells, Azacitidine also has immunomodulatory functions which could explain at least in part its effect in MDS-related AID. Azacitidine can indeed expand CD4+CD25+/FOXP3+ regulatory $T$ cells which are decreased with impaired suppressive function in many AID [19]. Azacitidine also increases expression of anti-inflammatory molecules like IFNY and could inhibit CD4+ T-cells and reduce immune-mediated cytotoxicity [11]. Azacitidine could finally decrease the synthesis of inflammatory cytokines like IL-6 [20]. In some cases, Azacitidine therefore could have a positive immunomodulatory effect, even when it is not active on MDS/CMML.

In conclusion, our results suggest that Azacitidine can improve the control of AID associated to MDS/CMML and allow to reduce steroid dose in most patients with MDS and concurrent AID. Prospective studies are necessary to confirm this beneficial effect and the safety of Azacitidine in AID associated with MDS/CMML.

Financial disclosure: There is no relevant financial relationship to declare for all authors.

\section{Contributions}

FJB performed the research; MA, FP, FO and BT designed the research study; FJB analysed the data; GE, KJE, AJB, DO, DG, BAL, OM, MG, AA, LN, BS, LE, PS, GC, LO, RJ, FP, FO and BT share data on patients; and FJB wrote the paper.

\section{ACKNOELEDGMENT}

There are no relevant funding sources to declare. 


\section{References}

[1] Braun T, Fenaux P. Myelodysplastic Syndromes (MDS) and autoimmune disorders (AD): cause or consequence? Best Pract Res Clin Haematol 2013;26:327-36. doi:10.1016/j.beha.2013.09.003.

[2] Mekinian A, Braun T, Decaux O, Falgarone G, Toussirot E, Raffray L, et al. Inflammatory arthritis in patients with myelodysplastic syndromes: a multicenter retrospective study and literature review of 68 cases. Medicine (Baltimore) 2014;93:1-10. doi:10.1097/MD.0000000000000011.

[3] Albert DA, Burns CM. Rheumatologic manifestations in myelodysplastic syndrome. J Clin Rheumatol Pract Rep Rheum Musculoskelet Dis 2012;18:148-50. doi:10.1097/RHU.0b013e31825003e4.

[4] Prat L, Bouaziz J-D, Wallach D, Vignon-Pennamen M-D, Bagot M. Neutrophilic dermatoses as systemic diseases. Clin Dermatol 2014;32:376-88. doi:10.1016/j.clindermatol.2013.11.004.

[5] Fenaux P, Mufti GJ, Hellstrom-Lindberg E, Santini V, Finelli C, Giagounidis A, et al. Efficacy of azacitidine compared with that of conventional care regimens in the treatment of higher-risk myelodysplastic syndromes: a randomised, open-label, phase III study. Lancet Oncol 2009;10:223-32. doi:10.1016/S1470-2045(09)70003-8.

[6] Costa R, Abdulhaq H, Haq B, Shadduck RK, Latsko J, Zenati M, et al. Activity of azacitidine in chronic myelomonocytic leukemia. Cancer 2011;117:2690-6. doi:10.1002/cncr.25759.

[7] Fianchi L, Criscuolo M, Breccia M, Maurillo L, Salvi F, Musto P, et al. High rate of remissions in chronic myelomonocytic leukemia treated with 5-azacytidine: results of an Italian retrospective study. Leuk Lymphoma 2013;54:658-61. doi:10.3109/10428194.2012.719617.

[8] Raj K, Ho A, Creamer JD, du Vivier AWP, Salisbury JR, Mufti GJ. Complete response of deep neutrophilic dermatosis associated with myelodysplastic syndrome to 5-azacytidine. $\mathrm{Br} \mathrm{J}$ Dermatol 2007;156:1039-41. doi:10.1111/j.1365-2133.2007.07831.x.

[9] Al Ustwani O, Francis J, Wallace PK, Ambrus J, Wetzler M. Treating myelodysplastic syndrome improves an accompanying autoimmune disease along with a reduction in regulatory T-cells. Leuk Res 2011;35:e35-6. doi:10.1016/j.leukres.2010.12.015.

[10] Pilorge S, Doleris LM, Dreyfus F, Park S. The autoimmune manifestations associated with myelodysplastic syndrome respond to 5-azacytidine: a report on three cases. $\mathrm{Br} J$ Haematol 2011;153:664-5. doi:10.1111/j.1365-2141.2010.08557.x.

[11] Frietsch JJ, Dornaus S, Neumann T, Scholl S, Schmidt V, Kunert C, et al. Paraneoplastic inflammation in myelodysplastic syndrome or bone marrow failure: case series with focus on 5azacytidine and literature review. Eur J Haematol 2014;93:247-59. doi:10.1111/ejh.12311.

[12] Tanaka H, Shimizu N, Tougasaki E, Kawajiri C, Hashimoto S, Takeda Y, et al. Successful treatment by azacitidine therapy of intestinal Behçet's disease associated with myelodysplastic syndrome. Int J Hematol 2013;97:520-4. doi:10.1007/s12185-013-1316-x.

[13] Mekinian A, Grignano E, Braun T, Decaux O, Liozon E, Costedoat-Chalumeau N, et al. Systemic inflammatory and autoimmune manifestations associated with myelodysplastic syndromes and chronic myelomonocytic leukaemia: a French multicentre retrospective study. Rheumatol Oxf Engl 2015. doi:10.1093/rheumatology/kev294.

[14] Gyan E, Andrieu V, Sanna A, Caille A, Schemenau J, Sudaka I, et al. Myelodysplastic syndromes with single neutropenia or thrombocytopenia are rarely refractory cytopenias with unilineage dysplasia by World Health Organization 2008 criteria and have favourable prognosis. $\mathrm{Br} \mathrm{J}$ Haematol 2016. doi:10.1111/bjh.13902.

[15] Wanquet A, Prebet T, Berthon C, Sebert M, Roux C, Kulasekararaj A, et al. Azacitidine treatment for patients with myelodysplastic syndrome and acute myeloid leukemia with chromosome $3 q$ abnormalities. Am J Hematol 2015;90:859-63. doi:10.1002/ajh.24099.

[16] Damaj G, Mohty M, Robin M, Michallet M, Chevallier P, Beguin Y, et al. Upfront allogeneic stem cell transplantation after reduced-intensity/nonmyeloablative conditioning for patients with myelodysplastic syndrome: a study by the Société Française de Greffe de Moelle et de Thérapie 
Cellulaire. Biol Blood Marrow Transplant J Am Soc Blood Marrow Transplant 2014;20:1349-55. doi:10.1016/j.bbmt.2014.05.010.

[17] Shoenfeld Y, Cervera R, Gershwin ME, editors. Diagnostic Criteria in Autoimmune Diseases. Totowa, NJ: Humana Press; 2008.

[18] Cheson BD. Clinical application and proposal for modification of the International Working Group (IWG) response criteria in myelodysplasia. Blood 2006;108:419-25. doi:10.1182/blood2005-10-4149.

[19] Goodyear OC, Dennis M, Jilani NY, Loke J, Siddique S, Ryan G, et al. Azacitidine augments expansion of regulatory $T$ cells after allogeneic stem cell transplantation in patients with acute myeloid leukemia (AML). Blood 2012;119:3361-9. doi:10.1182/blood-2011-09-377044.

[20] Poplutz MK, Wessels I, Rink L, Uciechowski P. Regulation of the Interleukin-6 gene expression during monocytic differentiation of $\mathrm{HL}-60$ cells by chromatin remodeling and methylation. Immunobiology 2014;219:619-26. doi:10.1016/j.imbio.2014.03.016. 


\section{GFM registry $(n=4202)$ \\ MDS/CMML without AID $(n=4122)$}

MDS/CMML with AID $(n=80)$

Untreated with AZA $(n=67)$

\section{MDS/CMML with AID} treated by AZA $(n=13)$

- Inadequate follow up $(n=3)$ *

- AID remission at AZA onset $(n=1)$ *

Included $(n=9)$
SNFMI registry $(n=123)$ MDS/CMML with AID

Untreated with

AZA (n=108)

\section{MDS/CMML with AID treated by AZA $(n=15)$}

- Included in GFM ( $n=3)$

- Inadequate follow up $(n=2)$ *

- AID remission at AZA onset $(n=2)$ *

Included $(\mathrm{n}=\mathbf{8})$ 
Table 1: Patient characteristics at baseline and after AZA treatment

\begin{tabular}{|c|c|c|c|c|c|c|c|c|c|c|c|c|c|c|}
\hline $\begin{array}{l}\text { Gender, } \\
\text { Age }\end{array}$ & $\begin{array}{l}\text { WHO classification } \\
\text { karyotype }\end{array}$ & IPSS & $\begin{array}{c}\text { Interval from } \\
\text { MDS } \\
\text { diagnosis } \\
\text { to AZA } \\
\text { treatment } \\
\text { (months) } \\
\end{array}$ & Type of AID & IST failure & $\begin{array}{c}\text { AID status at } \\
\text { AZA onset }\end{array}$ & $\begin{array}{l}\text { Clinical signs of } \\
\text { AID at AZA onset }\end{array}$ & $\begin{array}{c}\text { Steroids } \\
(\mathrm{mg} / \mathrm{d}) \\
\text { before/ } \\
\text { after AZA }\end{array}$ & $\begin{array}{c}\text { IST } \\
\text { Before/ } \\
\text { after AZA }\end{array}$ & $\begin{array}{c}\mathrm{CRP}(\mathrm{mg} / \mathrm{L}) \\
\text { before/ after } \\
\text { AZA }\end{array}$ & $\begin{array}{l}\text { Response of } \\
\text { MDS to AZA }\end{array}$ & $\begin{array}{l}\text { Response of } \\
\text { AID to AZA }\end{array}$ & $\begin{array}{l}\text { Clinical signs } \\
\text { after AZA }\end{array}$ & $\begin{array}{l}\text { Duration of } \\
\text { AID response } \\
\text { (months) }\end{array}$ \\
\hline $1, \mathrm{~F} 57$ & $\begin{array}{c}\text { RAEB2 } \\
48, X X+8,+9\end{array}$ & Int-2 & 2 & Behçet & Thal & $\mathrm{F}$ & As Fe Sk, Ap Thr & $0 / 0$ & Thal/Thal & $40 / 60$ & $C R$ & $C R$ & None & $7+$ \\
\hline $2, F 82$ & $\begin{array}{c}\mathrm{RCMD} \\
49, \mathrm{XX}, \mathrm{del}(7 \mathrm{q}),+8 \\
+14,+21 \\
\end{array}$ & High & 11 & Behçet & Col & PR & WL As Ap & $5 / 5$ & Col/ None & $10 / 30$ & SD & CR & WL As & $5+$ \\
\hline $3, F 79$ & $\begin{array}{c}\text { RAEB1 } \\
46, \mathrm{XX} \text {, del(20q) } \\
\end{array}$ & Int-1 & 5 & PA & SLZ & PR & AsJI & $15 / 5$ & SLZ/ SLZ & $15 / 0$ & SD HI-E & $C R$ & None & $7+$ \\
\hline $4, M, 78$ & $\begin{array}{l}\text { RAEB2 } \\
46, X Y\end{array}$ & Int-2 & 8 & PMR & None & PR & لا & $25 / 15$ & None/ None & $12 / 15$ & SD & $C R$ & None & 19 \\
\hline $5, M, 76$ & $\begin{array}{l}\text { RAEBt } \\
46 \mathrm{XY}\end{array}$ & Int-2 & 1 & SLE & RTX & $C R$ & As & $10 / 10$ & $\begin{array}{l}\text { HCQ, MMF } \\
\text { / None }\end{array}$ & $5 / 25$ & SD & $C R$ & None & $13+$ \\
\hline $\begin{array}{l}6, M, \\
66[10]\end{array}$ & $\begin{array}{l}\text { CMML } \\
46, X Y\end{array}$ & Int-1 & 4 & SS / APLS & $\begin{array}{l}\text { MTX CYC } \\
\text { MMF }\end{array}$ & $\mathrm{F}$ & As Sk JI Lu & $20 / 8$ & MMF/ None & $\mathrm{NA} / 5$ & $C R$ & $C R$ & None & $10+$ \\
\hline $7, F, 61$ & $\begin{array}{c}\text { RAEB2 } \\
46, X X, \text { del(5q), } \\
\text { del(17p) }\end{array}$ & High & 0 & Sweet & None & $\mathrm{F}$ & WL As Fe Sk JI & $50 / 0$ & None/ None & $54 / 3$ & Prog & $C R$ & None & $8+$ \\
\hline $8, M, 41$ & $\begin{array}{c}\mathrm{RCMD} \\
50, \mathrm{XY},+7,+7,+8,+8\end{array}$ & Int-1 & 0 & Behçet & ANA & $\mathrm{F}$ & $\begin{array}{l}\text { WL As Fe Sk Ap Jl } \\
\text { Gl }\end{array}$ & $20 / 20$ & ANA/ ANA & $300 / 50$ & SD & PR & Sk & $4+$ \\
\hline $9, M, 69$ & $\begin{array}{l}\text { RAEB2 } \\
47, X Y,+8\end{array}$ & High & 22 & Behçet & None & $\mathrm{F}$ & $\begin{array}{c}\text { WL As Fe Sk Ap Jl } \\
\text { Gl }\end{array}$ & $60 / 0$ & None/ None & $8 / 5$ & SD & $C R$ & None & $23+$ \\
\hline $10, M, 74$ & $\begin{array}{l}\text { RAEB1 } \\
46, X Y\end{array}$ & Low & 23 & SLE & HCQ MTX & $C R$ & None & $10 / 5$ & $\mathrm{HCO} / \mathrm{HCQ}$ & $0 / 0$ & $C R$ & $C R$ & None & $9+$ \\
\hline $11, M, 81$ & $\begin{array}{c}\text { Unclassified } \\
47, X Y,+8, t(3-5)\end{array}$ & Int-2 & 16 & SVV & Col & $\mathrm{F}$ & WL PN & $0 / 0$ & None/ None & $82 / 67$ & SD & NR & As JI PN & \\
\hline $12, F, 76$ & $\begin{array}{l}\text { RCMD } \\
46, X X\end{array}$ & Int-2 & 9 & Vasculitis & None & $\mathrm{F}$ & WL As Fe Sk JI & $60 / 10$ & None/ None & $20 / \mathrm{NA}$ & SD & $C R$ & As, $\mathrm{Fe}$ & $7+$ \\
\hline $13, M, 80$ & $\begin{array}{l}\text { RAEB2 } \\
46, X Y\end{array}$ & Int-2 & 62 & PMR & None & PR & As & $13 / 13$ & None/ None & $5 / 146$ & SD & NR & As & \\
\hline $14, F, 70$ & $\begin{array}{l}\text { CMML } \\
46, X X\end{array}$ & Int-2 & 74 & GCA \& PMR & None & PR & As JI & $40 / 8$ & None/ None & $11 / 2$ & PR & $C R$ & As & 19 \\
\hline
\end{tabular}




\begin{tabular}{|c|c|c|c|c|c|c|c|c|c|c|c|c|c|c|}
\hline $15, M, 67$ & $\begin{array}{l}\text { RAEB1 } \\
46, X Y\end{array}$ & Low & 59 & PC & IFX ANA & $\mathrm{F}$ & As Sk Jl & $25 / 30$ & ANA/ None & $50 / 60$ & $C R$ & $C R$ & None & \\
\hline $16, M, 57$ & $\begin{array}{c}R A \\
46, X Y\end{array}$ & Low & 26 & PC & IFX MTX CYC & $\mathrm{F}$ & As Sk JI ENT & $15 / 18$ & None/ None & $248 / 10$ & $C R$ & PR & CNS & $9+$ \\
\hline $17, M, 67$ & $\begin{array}{c}\text { Del-5q MDS } \\
46, X Y, \text { del(5q) }\end{array}$ & Int-1 & 93 & PC \& Sweet & $\mathrm{CIC}$ & $\mathrm{F}$ & $\begin{array}{c}\text { WL As Fe Sk JI Lu } \\
\text { ENT }\end{array}$ & $80 / 5$ & None/ None & $240 / \mathrm{NA}$ & $C R$ & $C R$ & None & $8+$ \\
\hline $18, M, 66$ & $\begin{array}{l}\text { RAEB1 } \\
46, X Y\end{array}$ & Int-1 & 0 & GCA & $\begin{array}{l}\text { ANA IFX } \\
\text { MTX TCZ } \\
\text { IVIG CIC }\end{array}$ & $\mathrm{F}$ & As Sk ENT & $40 / 0$ & IVIG/ None & $146 / 22$ & $C R$ & $C R$ & None & $9+$ \\
\hline $19, M, 84$ & $\begin{array}{l}\text { RCMD } \\
46, X Y\end{array}$ & Int-1 & 8 & PMR & Col & $\mathrm{F}$ & As Sk JI & $17 / 15$ & None/ None & $61 / 143$ & $\mathrm{mCR}$ & NR & Fe JI & 3 \\
\hline $20, M, 47$ & $\begin{array}{c}\mathrm{RCMD} \\
47, \mathrm{XY},+8\end{array}$ & Int-1 & 9 & Still & $\begin{array}{c}\text { Col MTX } \\
\text { ANA TCZ } \\
\text { HCQ } \\
\end{array}$ & $\mathrm{F}$ & $\begin{array}{l}\text { WL As Fe, II ENT } \\
\text { PN }\end{array}$ & $40 / 16$ & $\begin{array}{l}\text { ANA, HCQ } \\
\text { / None }\end{array}$ & $38 / \mathrm{NA}$ & $C R$ & PR & $\mathrm{J}$ & $2+$ \\
\hline $21, \mathrm{M}, 64$ & $\begin{array}{l}\text { RAEBt } \\
46, X Y\end{array}$ & Int-2 & 2 & PC & ETC & $\mathrm{F}$ & J & $80 / 5$ & None/ None & $161 / 14$ & Prog & $C R$ & None & 31 \\
\hline $22, M, 83$ & $\begin{array}{c}R A \\
46, X Y\end{array}$ & Int-1 & 11 & PC & AZA & $\mathrm{F}$ & J & $14 / 10$ & AZAT/None & $225 / 5$ & $C R$ & $C R$ & None & $3+$ \\
\hline
\end{tabular}

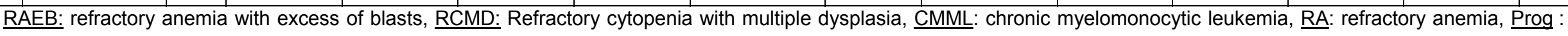

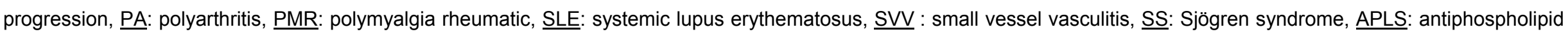

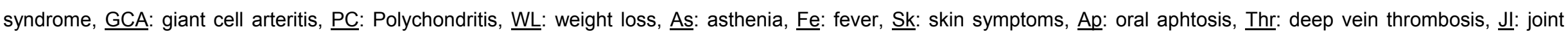
involvement, $\underline{\mathrm{Lu}}$ : lung involvement, $\underline{\mathrm{Gl}}$ : gastro intestinal symptoms, $\underline{\mathrm{PN}}$ : peripheral neuropathy, $\underline{\mathrm{CNS}}$ : central nervous system involvement, ENT: ears nose and throat symptoms, $\underline{\mathrm{HCQ}}$ : hydroxychloroquine, MMF: mycophenolate mofetil, $\underline{\mathrm{IVIG}}$ : intravenous immunoglobulin, Thal: Thalidomide, $\underline{\mathrm{CST}}$ : corticosteroids, $\underline{\text { Col: }}$ Colchicine, $\underline{\text { SLZ: }}$ salazopyrine, $\underline{\mathrm{RTX}}$ : Rituximab, MTX, methotrexate, $\underline{\mathrm{ANA}}$ : Anakinra, $\underline{\mathrm{CYC}}$ : cyclophosphamide, IFX: infliximab, $\underline{\mathrm{CIC}}$ : ciclosporine, $\underline{\mathrm{TCZ}}$ : tocilizumab, ETC: etanercept, $\underline{\text { AZA: }}$ azathioprine. $\underline{\mathrm{NA}}:$ not available, $\underline{\mathrm{CR}}$ : complete response, $\underline{\mathrm{PR}}:$ partial response, $\underline{\mathrm{NR}}$ : no response, $\underline{ \pm}$ absence of relapse at last follow-up. 
Table 2: Published cases of MDS/CMML with AID treated with Azacitidine

\begin{tabular}{|c|c|c|c|c|c|}
\hline Gender, Age & $\mathrm{MDS} / \mathrm{CMML}$ & IPSS & AID & IST failure & Evolution \\
\hline $1, \mathrm{M} 74[8]$ & RAEB2 & High & Sweet & & CR of MDS and AID \\
\hline $2, \mathrm{M} \mathrm{44[9]}$ & RCMD & Int-2 & SLE & $\mathrm{CST}, \mathrm{HCQ}$ & CR of MDS and AID \\
\hline $3, \mathrm{M}$ 69[10] & RCMD & Int-1 & Polyarthritis \& Sweet & $\begin{array}{l}\text { CST (40/d), colchicine, disulone, } \\
\text { thalidomide }\end{array}$ & $\begin{array}{l}\text { CR of MDS and AID } \\
\text { CST }(8 \mathrm{mg} / \mathrm{d})\end{array}$ \\
\hline $4, M, 66[10]$ & CMML & Int-1 & SS \& APLS & $\begin{array}{c}\text { CST }(20 \mathrm{mg} / \mathrm{d}), \mathrm{MMF} \\
\text { MTX, CYC, }\end{array}$ & $\begin{array}{c}\text { CR of MDS and AID } \\
\text { CST }(5 \mathrm{mg} / \mathrm{d}) \\
\text { MMF stopped }\end{array}$ \\
\hline $5, M, 64[10]$ & RAEB-1 & Int-1 & Polyarthritis \& Sweet & CST $(10 \mathrm{mg} / \mathrm{d})$, thalidomide. & $\begin{array}{l}\text { CR of MDS and AID } \\
\text { CST stopped }\end{array}$ \\
\hline $6, F, 52[11]$ & RAEB-2 & Int-2 & Polyarthritis \& Sweet & CST / MTX & $\begin{array}{c}\text { CR of AID } \\
\text { CST tapered } \\
\downarrow \text { transfusion }\end{array}$ \\
\hline $7, F, 73[11]$ & RAEB-2 & Int-2 & SLE & CST & CR of AID and MDS \\
\hline
\end{tabular}

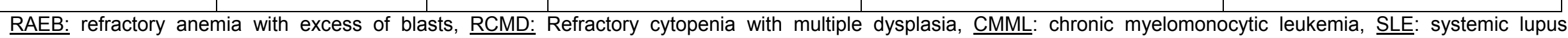

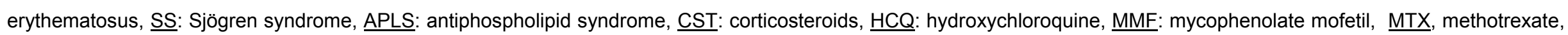
CR: complete response. 